\title{
Effect of cytokinins and auxin on bud burst and direct organogenesis in vitro of some sweet potato landraces (Ipomoea batatas L.) grown in Benin.
}

\author{
Arsène M. DOUSSOH ${ }^{*}$, Justine SOSSOU DANGOU2 ${ }^{2}$, Gilles H. T. CACAÏ1 ${ }^{1}$, Serge S. HOUEDJISSIN ${ }^{1}$ and \\ Corneille AHANHANZO ${ }^{1}$ \\ ${ }^{1}$ Central Laboratory of Plant Biotechnology and Plant Breeding, Department of Genetic and Biotechnology, Faculty of \\ Science and Technology, University of Abomey-Calavi, 01 BP 526, Cotonou, Republic of Benin. \\ 2Laboratory of Study and Research in Applied Chemistry, Polytechnic School of Abomey-Calavi, University of \\ Abomey-Calavi, 01 BP 2009, Cotonou, Republic of Benin \\ * Author corresponding: E-mail: dousserne@yahoo.fr ; Tel: +22997328559
}

Original submitted in on 10 th July 2018. Published online at www.m.elewa.org on $30^{\text {th }}$ November 2018 https://dx.doi.org/10.4314/jab.v131i1.9

\begin{abstract}
Objectives: Ipomoea batatas L. is a tuberous root plant of great nutritional and economic importance in Benin. This study aims to analyze the effects of two cytokinins (Benzylaminopurine and kinetin) and a one auxin (Naphthalene Acetic Acid) on direct organogenesis in vitro of six sweet potato landraces in Benin.

Methodology and Results: Ten uninodal stems disinfected of each variety are cultivated on a Murashige and Skoog (MS) medium then transplanted onto other MS media with different combinations of Benzylaminopurine, Kinetin and Naphthalene Acetic Acid. Their vitroplants are also acclimatized. Analysis of variance was used for data analysis. The results showed that " Amitchéwin, Vobodouaho and Koïdokpon " have recorded the highest average bud burst $\left(12.67,12.33\right.$ and 11.67 respectively). The media $\mathrm{MS}+1$ mg. $\mathrm{I}^{-1} \mathrm{BAP}+0.1 \mathrm{mg} . \mathrm{I}^{-1} \mathrm{NAA}$ and $\mathrm{MS}+1 \mathrm{mg} . \mathrm{I}^{-1} \mathrm{Kin}+0.1 \mathrm{mg}^{-\mathrm{I}^{-1} \mathrm{NAA}}$ were found more effective for the organogenesis of the varieties. Vitroplants of each variety acclimatized well with survival rates ranging from $56.66 \%$ to $83.33 \%$.

Conclusion: and application of results: The results showed that the combination of $1 \mathrm{mg.l}^{-1}$ of Benzylaminopurine or kinetin with $0.1 \mathrm{mg} . \mathrm{I}^{-1}$ of Naphthalene Acetic Acid was effective for in vitro organogenesis of sweet potato landraces used with well-acclimated vitroplants. This study paves the way for the establishment of in vitro collection of sweet potato landraces in Benin with a view to their ex situ preservation. Keywords: Ipomoea batatas; growth regulators; organogenesis in vitro; Acclimation; Benin.
\end{abstract}

\section{INTRODUCTION}

Sweet potato (Ipomoea batatas) is part of roots and tubers reproducing mainly by vegetative way whose performance is high and ranked second in the world after potatoes (Deng et al., 2012; Ndagijimana et al., 2014). It is increasingly produced in Benin, especially in the south of the country by small producers as a food during the lean season because of its ability to adapt to difficult conditions and its nutritional importance (Adégbloba, 2003; Sanoussi et al., 2013). Previous work on the species in Benin has shown the existence of a diversity of sweet potato landraces, some of which are increasingly neglected because of the many constraints that hinder production and whose conservation becomes a priority (Doussoh et al., 2016; Paraïso et al., 2013; Sanoussi et al., 2016). In vitro culture techniques are 
an alternative that is widely used for regeneration and transformation of sweet potato plants (Onwubiko et al., 2015). Thus, in vitro vegetative propagation is an important tool for the recovery, the multiplication and ex situ of preservation germplasm of species. It is also useful for the future improvement of breeding programs for the production of new more efficient and tolerant (Kamal et al., 2015;Saucedo-Ruiz et al., 2006; Sivparsad and Gubba, 2012). The success of micropropagation depends on several factors including the genotype and type of explants used (uninodal stems or leaf fragments, meristems), the disinfection protocol used (sodium hypochlorite, mercuric chloride), the growing conditions (temperature, brightness, humidity), the culture medium and its composition in growth regulators (Ahanhanzo et al., 2010; Cacai et al., 2012; Glato et al., 2013). Growth regulators play a decisive role in the orientation of culture an organogenesis or somatic embryogenesis (Delgado-Paredes et al., 2016; Demeke et al., 2014; Onwubiko et al., 2015). Auxins and cytokinins or their synthetic analogs are the most used growth regulators and the ratio of their combination determines the proliferation of roots, leaves and shoot length (Ezeibekwe et al., 2009). Auxins commonly used are naphthalene acetic acid (NAA), indole acetic acid (IAA), while cytokinins most

\section{MATERIAL AND METHODS}

Plant material and production of mother plants : The plant material constituted six (6) sweet potato landraces (Table 1) collected in southern and central Benin during September 2015 to February 2016 (Doussoh et al., 2016). "Dokoui carotte" and "Koïdokpon" were selected because they are increasingly neglected while their colored flesh represents an indicator of richness in vitamins $A$. Amitchéwin, Dokoui èlèhin akpao, 'Bombo wéwé and Vobodouaho were selected on the basis of the preference criteria of the producers (Precocity, high multiplication rate, high market value and good post-harvest conservation) (Doussoh et al., 2016). These different used are kinetin, benzyl amino purine (BAP). Preliminary work on the introduction of sweet potato in vitro culture in Benin has been completed. These work used explants and disinfected uninodal stems and mercuric chloride respectively with an effective dose of disinfection of $0.5 \%$ on three sweet potato landraces (Doussoh et al., 2017). Similarly, MS (Murashige and Skoog) with or without naphthalene acetic acid and benzyl amino purine have been used to regenerate sweet potato in vitro with vegetative organs formation including leaves, roots, shoots. However, no study has been conducted on the organogenesis in vitro for creation of in vitro collection of sweet potato landraces and the use of their apex and meristems in ex situ preservation protocols. The present work aims to improve the production of vitroplants of sweet potato landraces from uninodal stems fragments on MS media with different combinations of naphthalene acetic acid, benzyl amino purine and kinetin. Specific objectives were: (a) to evaluate the rate of bud burst of six sweet potato landraces on an MS initiation medium; (b) to determine the influence of the hormonal combinations of naphthalene acetic acid, benzyl amino purine and kinetin on the formation of shoots, leaves and roots; (c) to acclimate vitroplants rooted on an organic substrate.

landraces are morphologically different from each other. Their cuttings were disinfected with a fungicide, the methylthiophanate at $70 \%$ and were grown in polyethylene pots filled with treated soil by nematicide (carbofurant). The pots were maintained in the ender greenhouse of Genetic and Biotechnology Department of Central Laboratory of Plant Biotechnology and Breeding Plant (LCBVAP) of the Faculty of Science and Techniques of the University of Abomey-Calavi. After six weeks of culture, young shoots were then obtained as mother plants. 

vitro of some sweet potato landraces (Ipomoea batatas L.) grown in Benin.

Table 1: Characteristics of landraces used.

\begin{tabular}{l|c|c|c}
\hline Landraces & Characteristics of tubers & Collecting municipality & $\begin{array}{c}\text { Production cycle } \\
\text { (months) }\end{array}$ \\
\hline Amitchewin & Dark purple skin, yellow flesh & Sissèkpa (adjohoun) & 4 \\
Bombo wéwé & White skin, yellow flesh & Sokan (Abomey-Calavi) & 4 \\
Doki èlèhin akpao & Red skin, white flesh & Takou (Kétou) & $3-4$ \\
Dokoui carotte & Orange skin and flesh & Glo Fanto (Abomey-Calavi) & $3-4$ \\
Koïdokpon & Red skin, yellow flesh & Glo Fanto (Abomey-Calavi) & $4-5$ \\
Vobodouaho & White skin and flesh & Kpoto (Zangnanando) & 3 \\
\hline
\end{tabular}

Culture media : Seven (7) culture media were used with MS medium (Murashige and Skoog, 1962) as a base supplemented with naphthalene acetic acid (NAA), benzyl amino purine (BAP) and kinetin at different concentrations (Table 2). The $\mathrm{pH}$ of the media is adjusted to $5.7 \pm 0.1$. The media supplemented with $30 \mathrm{~g} \cdot \mathrm{L}^{-1}$ sucrose and $8 \mathrm{g.L}$ 1 agar were distributed in tubes $(25 \mathrm{~mm} \times 150 \mathrm{~mm})$, sterilized at $121^{\circ} \mathrm{C}$ for 15 minutes in an autoclave and transferred to the culture chamber. The seeded media were placed in the culture chamber at $27 \pm 1^{\circ} \mathrm{C}$ and were subjected to a photoperiod of 16 hours per day under a light intensity of 5000 lux provided by Philips TLD18W and Sibalec lamps. The relative humidity is maintained at $80 \%$.

Table 2 : Composition of culture media

\begin{tabular}{|c|c|}
\hline Culture media & Composition in growth regulators \\
\hline $\mathbf{M}_{\mathbf{l}}$ & MS without growth regulators \\
\hline$M_{\|}$ & $\mathrm{MS}+1 \mathrm{mg} \cdot \mathrm{l}^{-1} \mathrm{BAP}$ \\
\hline$M_{\mathrm{II}}$ & $\mathrm{MS}+1 \mathrm{mg} \cdot \mathrm{l}^{-1} \mathrm{BAP}+0,1 \mathrm{mg} \cdot \mathrm{I}^{-1} \mathrm{NAA}$ \\
\hline Miv & $\mathrm{MS}+1 \mathrm{mg} \cdot \mathrm{ll}^{-1} \mathrm{Kin}$ \\
\hline Mv & $\mathrm{MS}+1 \mathrm{mg} \cdot \mathrm{l}^{-1} \mathrm{Kin}+0,1 \mathrm{mg} \cdot \mathrm{l}^{-1} \mathrm{NAA}$ \\
\hline Mvi & $\mathrm{MS}+0,5 \mathrm{mg} \cdot \mathrm{I}^{-1} \mathrm{BAP}+0,5 \mathrm{mg} \cdot \mathrm{I}^{-1} \mathrm{Kin}$ \\
\hline MviI & $\mathrm{MS}+0,5 \mathrm{mg} . \mathrm{I}^{-1} \mathrm{BAP}+0,5 \mathrm{mg} . \mathrm{I}^{-1} \mathrm{Kin}+0,1 \mathrm{mg} . \mathrm{I}^{-1} \mathrm{NAA}$ \\
\hline
\end{tabular}

Disinfection of explants and initiation of shoots. : The disinfection protocol applied was that using $0.5 \%$ mercuric chloride (Ahanhanzo et al., 2008; Doussoh et al., 2017). Fragments of uninodal stems of the six landraces were used as explants and are then taken from the mother plants. Fragments were cleared of their leaves and rinsed with tap water and were transferred to the culture chamber under hood. They were then immersed in $70 \%$ alcohol for $1 \mathrm{~min}$ and then dipped in a $0.5 \%$ mercuric chloride solution containing two drops of Tween 80 for 10 $\mathrm{min}$. The explants were rinsed three times with distilled water sterilized for five minutes per rinsing. The disinfected explants were rid of their necrosed parts by a scalpel. Each explant of about $3 \mathrm{~cm}$ with a node was placed in a test tube containing MI medium (MS without growth regulators). Each seeded tube is closed with sterile cotton and sealed with parafilm. The tubes were transferred to the culture chamber.

Micropropagation of the shoots formed: To evaluate the effect of the hormonal combinations on the in vitro organogenesis of the six landraces, the shoots from the Ml medium are cut into uninodal $2 \mathrm{~cm}$ fragments with a node and subcultured onto the seven culture media, the Ml medium serving as the witness.
Acclimatization: The vigorous vitroplants of each landrace having formed roots were acclimated to a substrate contained in plastic pots perforated at the base and $3 / 4$ filled. The substrate used consisted of a mixture of compost, sawdust and soil in the proportions $2: 1: 1$. This substrate was sterilized in an oven at $150^{\circ} \mathrm{C}$ for 2 hours. These pots were placed in acclimation tanks then in the greenhouse and watered with Shives solution.

Evaluation parameters: The number of explants budded and formed shoots of each landraces was determined after observations made every 48 hours for 14 days. As for in vitro organogenesis, the number of leaves, nodes, roots and the height of the shoots formed were evaluated after six weeks of culture. Finally, the survival rate of the acclimated vitroplants of each local variety was determined after four weeks.

Data analysis: The experimental device used was a completely random block. For bud burst, fifteen (15) explants per landrace were used with three repetitions. For organogenesis, each culture medium was considered a major factor and varieties as secondary factors. For each parameter evaluated, an average of ten (10) vitroplants was considered as the sample unit with three repetitions. An analysis of variance (ANOVA) preceded 

vitro of some sweet potato landraces (Ipomoea batatas L.) grown in Benin.

the tests of RYAN-JOINER and LEVENE was realized. The variables number of leaves, number of nodes and number of roots do not follow a normal distribution, the two first have undergone a logarithmic transformation and the number root variable, a square root transformation allowing them to tend towards normality. The Student-

\section{RESULTS}

Bud burst of the different landraces on the MS medium as a function of time: Bud burst of the different landraces on the MS medium was evaluated after 14
Newmann-Keuls test at the 5\% threshold was also used to compare averages. In terms of acclimation, ten (10) vitroplants of each local sweet potato variety were used with two repetitions. The different data analysis was carried out with XLSAT software.

days. The analysis of variance showed a highly significant difference for the variety factor $(p<0.001)$ (Table 3 ).

Table 3 : ANOVA of burd burst

\begin{tabular}{l|l|l|l}
\hline Source of variation & Degree of freedom & Average squares & Probability \\
\hline Varieties & 5 & 27.66 & $<0.001$ \\
Error & 12 & 2.5 & \\
Total & 17 & &
\end{tabular}

Figure 1 showed the average bud burst of different sweet potato landraces. " Amitchéwin " and "Vobodouaho " had the highest average bud burst (12.67 and 12.33 respectively) while; the lowest average bud burst (5.67) was obtained with " Doki èlèhin akpao ". The landraces "
Bombo wéwé " and "Koïdokpon " were the first to bud up after 2 days compared to " Doki èlèhin akpa " whose first budding explants were observed from the 6th day (Figure 2).

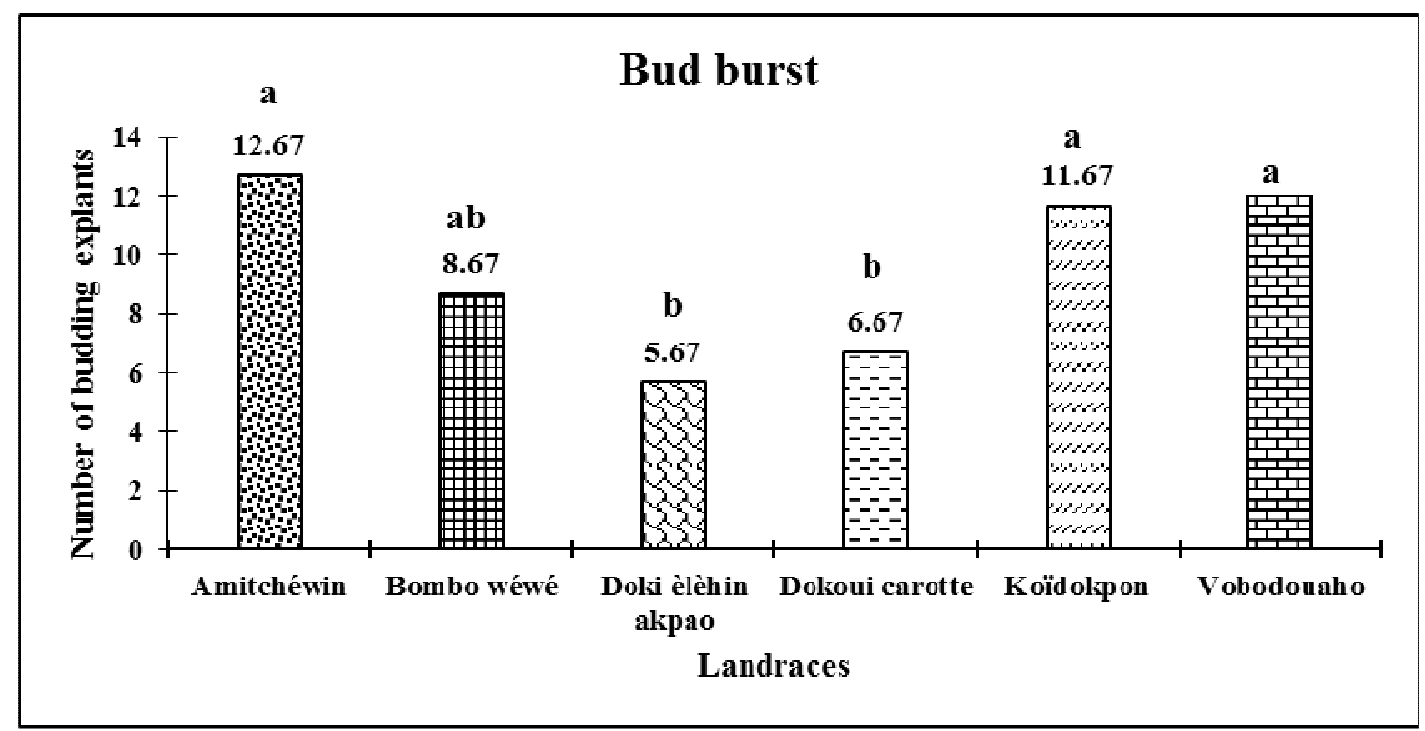

Figure 1 : Averages bud burst of six sweet potato landraces

Histograms with the same letter are not significantly different according to the Student, Newman and Keuls averaging test at the $5 \%$ threshold. 


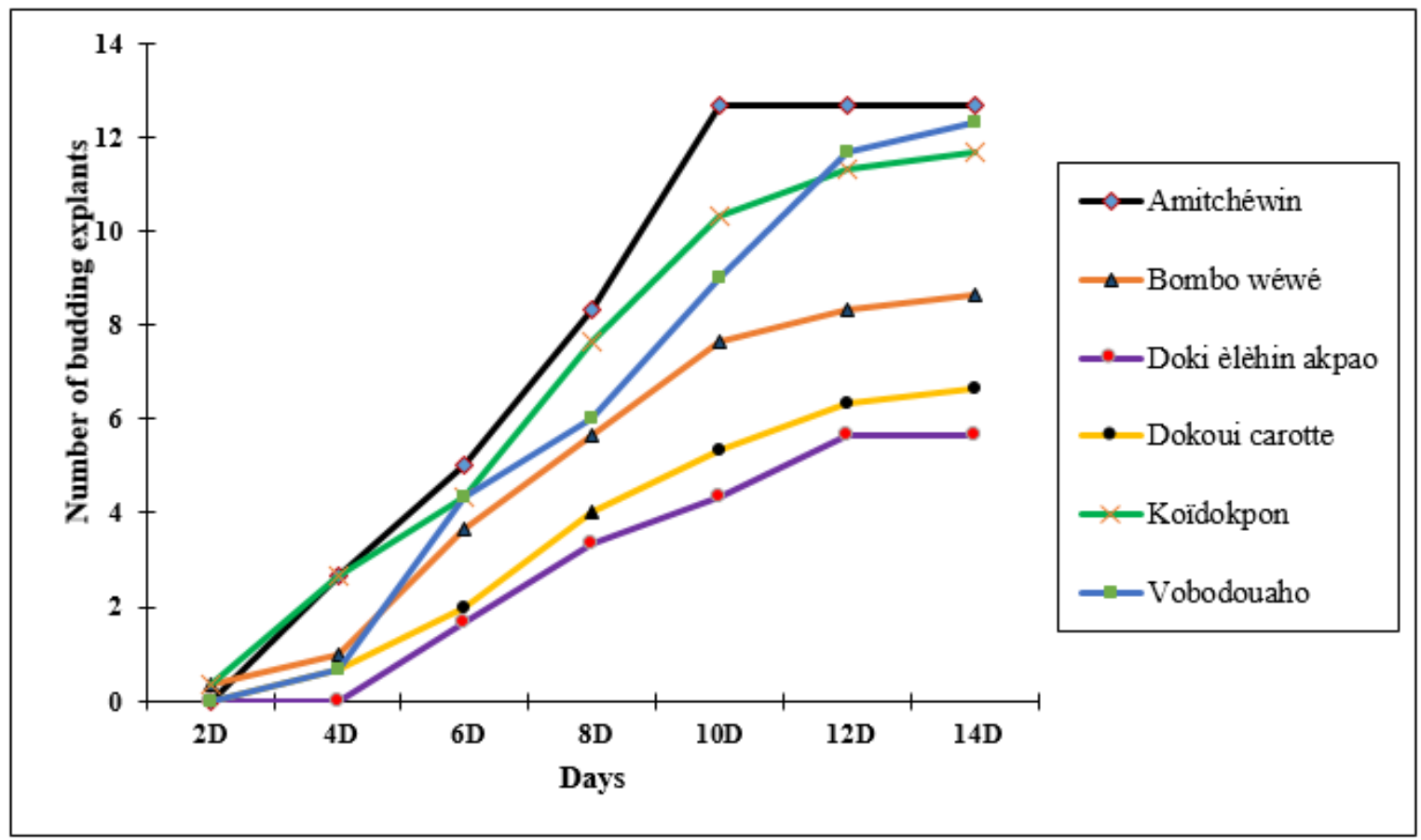

Figure 2 : Kinetics of bud burst of six sweet potato landraces over time.

Effect of the growth regulators on the organogenesis in vitro of six sweet potato landraces: In vitro organogenesis of sweet potato landraces was characterized by the formation and development of different growth organs (Figure 3). Analysis of variance of regulators on the formation of nodes, leaves, roots and shoot height were presented in Table 4.
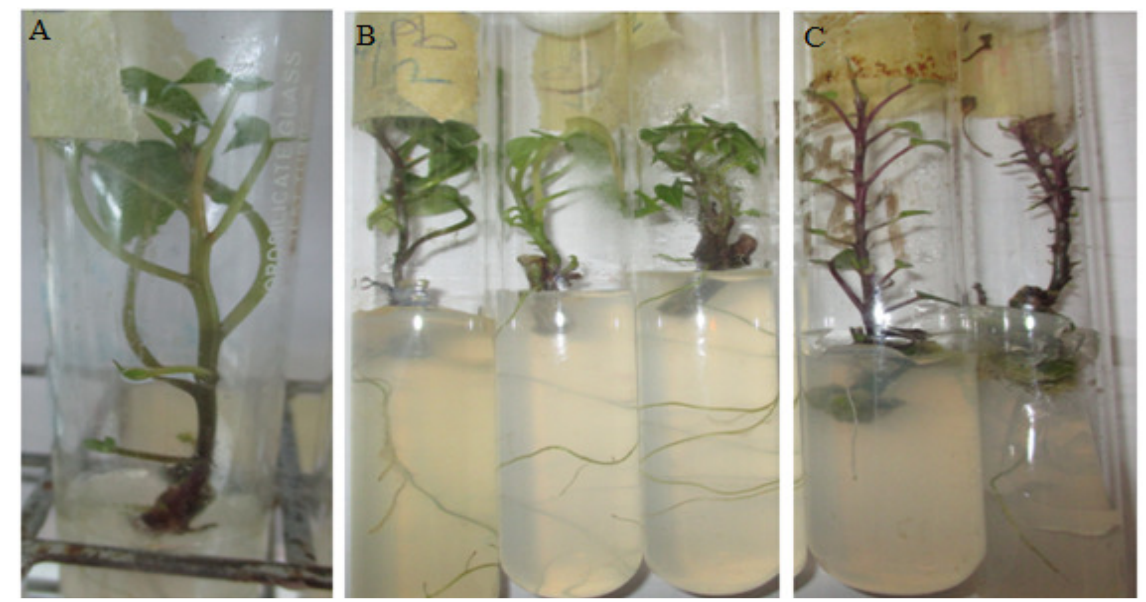

Figure 3 : Effect of grows regulators on organogenesis of three sweet potato landraces

A- Leaf formation of "Dokoui èlèhin akpao" on MII medium ; B- Root formation of "Vobodouaho on MIII medium ; C-Shoot formation of "Amitchéwin" on Ml medium 
Doussoh et al., J. Appl. Biosci. 2018 Effect of cytokinins and auxin on bud burst and direct organogenesis in vitro of some sweet potato landraces (Ipomoea batatas L.) grown in Benin.

Table 4 : ANOVA of the number of nodes, leaves, roots and shoots height.

\begin{tabular}{|c|c|c|c|}
\hline Source of variation & Degree of freedom & Average squares & Probability (P) \\
\hline \multicolumn{4}{|c|}{ Number of nodes } \\
\hline Varieties & 5 & 1.42 & $<0.001$ \\
\hline Medium & 6 & 0.12 & 0.010 \\
\hline Varieties *Medium & 30 & 0.25 & $<0.001$ \\
\hline Error & 84 & 0.04 & \\
\hline Total & 125 & & \\
\hline \multicolumn{4}{|c|}{ Number of leaves } \\
\hline Varieties & 5 & 1.46 & $<0.001$ \\
\hline Medium & 6 & 0.32 & $<0.001$ \\
\hline Varieties *Medium & 30 & 0.18 & $<0.001$ \\
\hline Error & 84 & 0.04 & \\
\hline Total & 125 & & \\
\hline \multicolumn{4}{|c|}{ Number of roots } \\
\hline Varieties & 5 & 0.27 & 0.229 \\
\hline Medium & 6 & 2.79 & $<0.001$ \\
\hline Varieties *Medium & 30 & 0.23 & 0.118 \\
\hline Error & 84 & 0.16 & \\
\hline Total & 125 & & \\
\hline \multicolumn{4}{|c|}{ Shoots height } \\
\hline Varieties & 5 & 31.50 & $<0.001$ \\
\hline Medium & 6 & 5.42 & $<0.001$ \\
\hline Varieties *Medium & 30 & 3.93 & $<0.001$ \\
\hline Error & 84 & 0.58 & \\
\hline Total & 125 & & \\
\hline
\end{tabular}

Effects of different growth regulators on nodes formation: The "Varieties" and "Medium" factors was showed respectively a highly significant difference $(P$ $<0.001)$ and a significant difference $(P=0.010)$ for the Logarithm of the number of nodes formed (Table 4). The interaction between these two factors is also highly significant $(P<0.001)$. Thus, the formation of the average number of nodes was varied significantly from one medium to another and from one variety to another.
Landraces "Amitchéwin", "Bombo wéwé" and "Koïdokpon" on MIII medium (MS + ANA + BAP) recorded the highest average of nodes $(12.66 ; 5.67$ and 8.33 respectively) while the highest averages of nodes were obtained for "Dokoui carotte" (5.67) and "Doki èlèhin akpao" (3.5) on MVI medium (MS + BAP + KIN) and Vobodouaho (6.67) on MV medium (MS + KIN + ANA) (Table 5).

Table 5: Average of nodes.

\begin{tabular}{l|c|c|c|c|c|c|c}
\hline \multicolumn{1}{c|}{ Media } & M I & M II & M III & M IV & M V & M VI & M VII \\
Varieties & & & & & & & \\
\hline Amitchéwin & $4.33 \pm$ & $7.00 \pm 3.6$ & $12.66 \pm$ & $7.33 \pm$ & $5.33 \pm$ & $5.67 \pm$ & $5.00 \pm$ \\
Bombo Wéwé & $1.15 \mathrm{c}$ & $\mathrm{ab}$ & $2.52 \mathrm{a}$ & $0.57 \mathrm{ab}$ & $1.15 \mathrm{bc}$ & $1.52 \mathrm{bc}$ & $1.73 \mathrm{bc}$ \\
& $3.33 \pm$ & $5.33 \pm$ & $5.67 \pm$ & $5 . .67 \pm$ & $4.67 \pm$ & $2,67 \pm$ & $4.33 \pm$ \\
Dokouin Carotte & $0.57 \mathrm{c}$ & $0.57 \mathrm{a}$ & $0.57 \mathrm{a}$ & $0.57 \mathrm{a}$ & $1.15 \mathrm{~b}$ & $0.57 \mathrm{c}$ & $0.57 \mathrm{bc}$ \\
& $4.33 \pm$ & $5.00 \pm 0.00$ & $5.00 \pm$ & $4.33 \pm$ & $4.00 \pm$ & $5.67 \pm$ & $5.33 \pm 0.67$ \\
Doki èlèhin akpao & $0.33 \mathrm{~b}$ & $\mathrm{ab}$ & $0.57 \mathrm{ab}$ & $0.33 \mathrm{~b}$ & $0.57 \mathrm{~b}$ & $0.67 \mathrm{a}$ & $\mathrm{a}$ \\
& $2.73 \pm$ & $3.43 \pm$ & $3.16 \pm$ & $2.03 \pm$ & $2.67 \pm$ & $3.50 \pm$ & $3.07 \pm$ \\
Koïdokpon & $0.28 \mathrm{ab}$ & $0.29 \mathrm{a}$ & $0.12 \mathrm{ab}$ & $0.31 \mathrm{~b}$ & $0.33 \mathrm{ab}$ & $0.28 \mathrm{a}$ & $0.24 \mathrm{ab}$ \\
& $2.33 \pm$ & $6.33 \pm$ & $8.33 \pm$ & $4.67 \pm$ & $6.00 \pm$ & $4.67 \pm$ & $3.67 \pm$ \\
Vobodouaho & $0.57 \mathrm{e}$ & $1.52 \mathrm{~b}$ & $0.57 \mathrm{a}$ & $1.15 \mathrm{c}$ & $1.00 \mathrm{bc}$ & $0.57 \mathrm{c}$ & $0.57 \mathrm{~d}$ \\
& $4.33 \pm$ & $6.33 \pm$ & $4.33 \pm$ & $5.33 \pm$ & $6.67 \pm$ & $5.67 \pm$ & $6.00 \pm$ \\
\hline
\end{tabular}

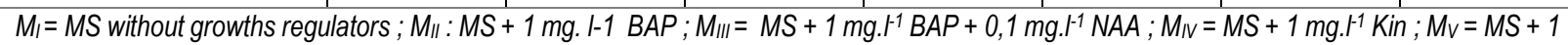
$\mathrm{mg} . \mathrm{l}^{-1} \mathrm{Kin}+0,1 \mathrm{mg} \cdot \mathrm{l}^{-1} \mathrm{NAA} ; \mathrm{Mvl}=\mathrm{MS}+0,5 \mathrm{mg} \cdot \mathrm{l}^{-1} \mathrm{BAP}+0,5 \mathrm{mg} \cdot \mathrm{l}^{-1} \mathrm{Kin} ; \mathrm{Mvll}=\mathrm{MS}+0,5 \mathrm{mg} \cdot \mathrm{l}^{-1} \mathrm{BAP}+0,5 \mathrm{mg} \cdot \mathrm{l}^{-1} \mathrm{Kin}+0,1 \mathrm{mg} \cdot \mathrm{l}^{-1} \mathrm{NAA}$. 

vitro of some sweet potato landraces (Ipomoea batatas L.) grown in Benin.

Effects of different growth regulators on leaves formation: The factors " Varieties " and " Medium " and the interaction between these two factors were showed for each a highly significant difference $(P<0.001)$ for the logarithm of the number of leaves formed (Table 4). Thus, for the leaves, their average number also varied significantly from one variety to another and from one medium to another. For "Amitchéwin", "Bombo wéwé" and "Koïdokpon" landraces, MIII medium (MS + BAP + ANA) was favoured the highest average leaves (respectively 11.86; 6 and 6.67). In contrast, the highest averages leaves were obtained for MVI medium for "Dokoui carotte" (5.67), MII medium for "Doki elehin akpao" (3.67) and MV medium for "Vobodouaho" (5.33). (Table 6).

Table 6 : Average of leaves

\begin{tabular}{l|c|c|c|c|c|c|c}
\hline \multirow{2}{*}{ Marieties } & M I & M II & M III & M IV & M V & M VI & M VII \\
\hline Amitchéwin & & & & & & & \\
Bombo Wéwé & $0.66 \pm$ & $6.66 \pm$ & $11.86 \pm$ & $6.33 \pm$ & $5.33 \pm$ & $6.67 \pm$ & $6.00 \pm$ \\
& $2.67 \pm$ & $3.06 \mathrm{~b}$ & $2.20 \mathrm{a}$ & $1.15 \mathrm{bc}$ & $0.57 \mathrm{c}$ & $0.57 \mathrm{~b}$ & $1.00 \mathrm{bc}$ \\
Dokouin Carotte & $1.15 \mathrm{~d}$ & $0.33 \pm$ & $6.00 \pm$ & $4.67 \pm$ & $5.67 \pm$ & $2.33 \pm$ & $4.33 \pm$ \\
& $4.33 \pm$ & $5.00 \pm$ & $1.00 \mathrm{a}$ & $0.57 \mathrm{c}$ & $1.15 \mathrm{a}$ & $0.57 \mathrm{~d}$ & $1.15 \mathrm{c}$ \\
Doki èlèhin akpao & $0.57 \mathrm{bc}$ & $1.00 \mathrm{ab}$ & $0.33 \pm$ & $4.67 \pm$ & $3.67 \pm$ & $5.67 \pm$ & $4.67 \pm$ \\
& $1.33 \pm$ & $3.67 \pm$ & $3.33 \pm$ & $0.57 \mathrm{~b}$ & $0.57 \mathrm{c}$ & $0.57 \mathrm{a}$ & $1.15 \mathrm{~b}$ \\
Koïdokpon & $0.57 \mathrm{c}$ & $0.57 \mathrm{a}$ & $0.57 \mathrm{ab}$ & $0.57 \mathrm{~b}$ & $0.57 \mathrm{~b}$ & $0.57 \mathrm{ab}$ & $0.57 \mathrm{ab}$ \\
& $3.00 \pm$ & $6.33 \pm$ & $6.67 \pm$ & $4.33 \pm$ & $5.00 \pm$ & $4.33 \pm$ & $4.33 \pm$ \\
Vobodouaho & $1.00 \mathrm{c}$ & $1.15 \mathrm{a}$ & $0.57 \mathrm{a}$ & $0.57 \mathrm{bc}$ & $1.00 \mathrm{~b}$ & $1.15 \mathrm{bc}$ & $0.57 \mathrm{bc}$ \\
& $2.67 \pm$ & $5.17 \pm$ & $4.67 \pm$ & $3.33 \pm$ & $5.33 \pm$ & $4.33 \pm$ & $4.67 \pm$ \\
\hline
\end{tabular}

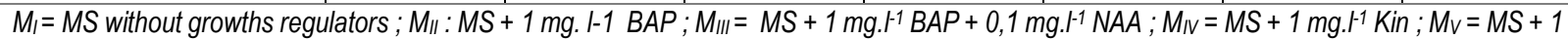

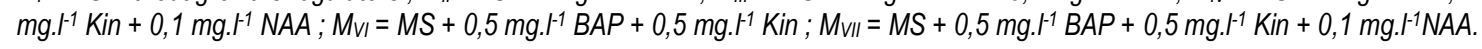

Effect of different growth regulators on roots formation: The factors " Varieties " and the interaction Varieties * Media were showed no significant difference ( $p$ $=0.22$ and 0.11 respectively) while the " Media " factor was showed a highly significant difference $(P<0.001)$ for the square root formed. Thus, for the roots, their average number varied significantly from one medium to another. The high average numbers of roots were obtained for "Amitchéwin" (2.33), "Dokoui carotte" (3.00) and "Koïdokpon" (2.93) on the medium MVII, "Bombo wéwé" (2.67) and "Doki èlèhin akpao" $(3,27)$ on MVI medium and "Vobodouaho" $(3,00)$ on MIII (Table 7).

Table 7 : Average of roots

\begin{tabular}{|c|c|c|c|c|c|c|c|}
\hline Varieties & M I & M II & M III & M IV & M V & M VI & M VII \\
\hline Amitchéwin & $\begin{array}{l}2.33 \pm \\
0.57 a\end{array}$ & $\begin{array}{l}1.53 \pm \\
0.61 b\end{array}$ & $\begin{array}{l}2.00 \pm \\
1.0 a b\end{array}$ & $\begin{array}{l}0.67 \pm \\
0.57 c\end{array}$ & $\begin{array}{l}1.33 \pm \\
0.57 \mathrm{~b}\end{array}$ & $\begin{array}{l}0.67 \pm \\
0.57 \mathrm{c}\end{array}$ & $\begin{array}{l}2.33 \pm \\
1.15 a\end{array}$ \\
\hline Bombo Wéwé & $\begin{array}{c}2.33 \pm \\
0.57 a\end{array}$ & $\begin{array}{l}0.67 \pm \\
0.57 c\end{array}$ & $\begin{array}{l}1.67 \pm \\
0.57 b\end{array}$ & $\begin{array}{c}0.33 \pm \\
0.27 \mathrm{c}\end{array}$ & $\begin{array}{c}2.67 \pm \\
0.77 \mathrm{a}\end{array}$ & $\begin{array}{c}0.33 \pm \\
0.57 c\end{array}$ & $\begin{array}{r}2.33 \pm \\
0.57 a\end{array}$ \\
\hline Dokouin Carotte & $\begin{array}{l}2.33 \pm \\
0.57 \mathrm{bc}\end{array}$ & $\begin{array}{l}0.67 \pm \\
0.15 \mathrm{de}\end{array}$ & $\begin{array}{c}2.67 \pm \\
0.57 \mathrm{~b}\end{array}$ & $\begin{array}{l}0.33 \pm \\
0.57 \mathrm{e}\end{array}$ & $\begin{array}{l}1.67 \pm \\
1.15 \mathrm{c}\end{array}$ & $\begin{array}{l}0.67 \pm \\
0.57 d\end{array}$ & $\begin{array}{l}3.00 \pm \\
0.10 \mathrm{a}\end{array}$ \\
\hline Doki èlèhin akpao & $\begin{array}{l}1.67 \pm \\
0.57 c\end{array}$ & $\begin{array}{l}1.20 \pm \\
1.00 \mathrm{~d}\end{array}$ & $\begin{array}{l}3.20 \pm \\
0.72 a\end{array}$ & $\begin{array}{l}0.67 \pm \\
0.15 d\end{array}$ & $\begin{array}{l}3.27 \pm \\
0.76 a\end{array}$ & $\begin{array}{l}1.82 \pm \\
0.20 \mathrm{c}\end{array}$ & $\begin{array}{l}2.40 \pm \\
0.36 \mathrm{~b}\end{array}$ \\
\hline Koïdokpon & $\begin{array}{l}1.67 \pm \\
0.57 \mathrm{c}\end{array}$ & $\begin{array}{l}0.67 \pm \\
0.57 d\end{array}$ & $\begin{array}{l}1.67 \pm \\
0.57 \mathrm{c}\end{array}$ & $\begin{array}{l}2.00 \pm \\
1.00 \mathrm{~b}\end{array}$ & $\begin{array}{l}2.46 \pm \\
0.53 \mathrm{ab}\end{array}$ & $\begin{array}{l}0.83 \pm \\
0.64 \mathrm{~cd}\end{array}$ & $\begin{array}{r}2.93 \pm \\
0.37 a\end{array}$ \\
\hline Vobodouaho & $\begin{array}{l}2.67 \pm \\
0.57 \mathrm{ab}\end{array}$ & $\begin{array}{l}1.93 \pm \\
1.30 \mathrm{~b}\end{array}$ & $\begin{array}{l}3.00 \pm \\
0.10 \mathrm{a}\end{array}$ & $\begin{array}{l}0.67 \pm \\
0.57 d\end{array}$ & $\begin{array}{l}1.667 \pm \\
0.577 \mathrm{c}\end{array}$ & $\begin{array}{l}1.33 \pm \\
0.57 c\end{array}$ & $\begin{array}{l}1.67 \pm \\
0.57 \mathrm{c}\end{array}$ \\
\hline
\end{tabular}

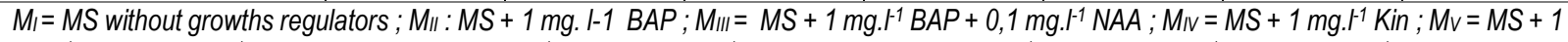
$\mathrm{mg} . \mathrm{l}^{-1} \mathrm{Kin}+0,1 \mathrm{mg} . \mathrm{l}^{-1} \mathrm{NAA} ; \mathrm{Mvl}=\mathrm{MS}+0,5 \mathrm{mg} . \mathrm{l}^{-1} \mathrm{BAP}+0,5 \mathrm{mg} . \mathrm{l}^{-1} \mathrm{Kin} ; \mathrm{Mvl}=\mathrm{MS}+0,5 \mathrm{mg} . \mathrm{l}^{-1} \mathrm{BAP}+0,5 \mathrm{mg} . \mathrm{H}^{-1} \mathrm{Kin}+0,1 \mathrm{mg} . \mathrm{l}^{-1} \mathrm{NAA}$. 

vitro of some sweet potato landraces (Ipomoea batatas L.) grown in Benin.

Effects of different growth regulators on the height of the shoots formed: The factors "Varieties " and "Media $"$ and their interaction showed a highly significant difference $(P<0.001)$ (Table 4). Thus, for shoot height, their average varied significantly from one variety to another and from one medium to another. The highest average shoot height was obtained for "Amitchéwin" $(8.10 \mathrm{~cm})$ and "Dokoui carotte" $(7.43 \mathrm{~cm})$ on medium $\mathrm{MVI}$, for "Bombo wéwé" $(8.23 \mathrm{~cm}$ ) and "Vobodouaho" $(7.83 \mathrm{~cm})$ on the medium MIV and for "Koïdokpon" (11.96 $\mathrm{cm})$ and doki èlèhin akpao $(5.56 \mathrm{~cm})$ on MIII medium (Figure 4).

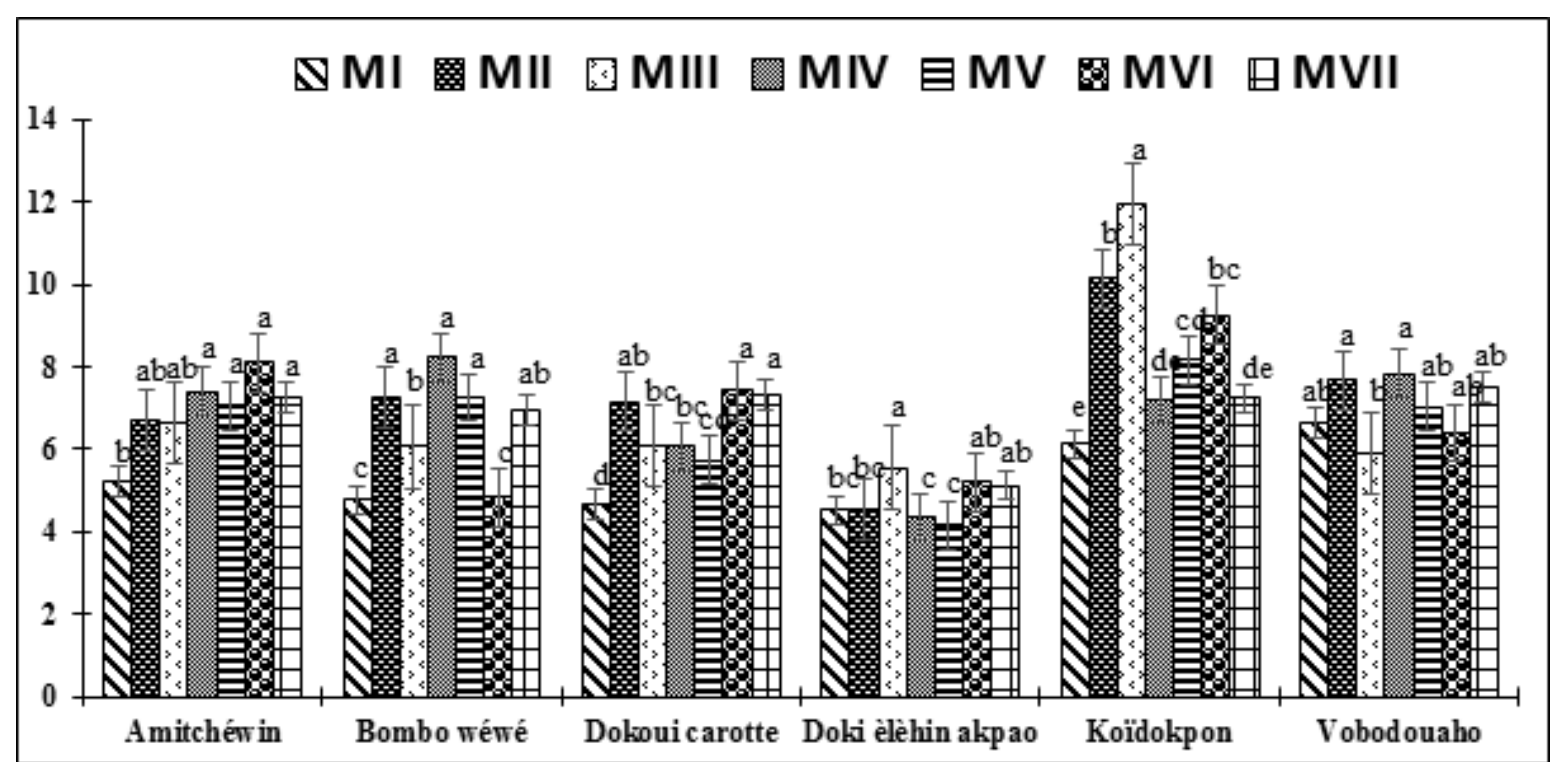

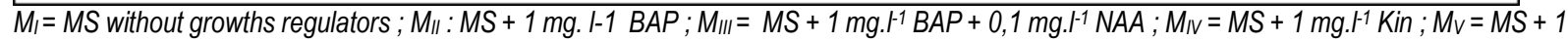

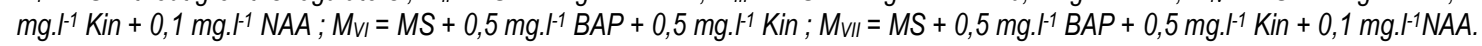

Figure 4 : Averages of the height of shoots formed.

Acclimatization of sweet potato vitroplants: Figure 5 showed the survival rates of the acclimated vitroplants of the landraces after six weeks of culture. The landraces "Amichéwin" and "Dokoui carrot" had the highest survival averages ( $80.33 \%$ and $80 \%$, respectively) compared to
"Bombo wéwé" and "Doki èlèhin akpao". The lowest survival averages ( $60 \%$ and $56.66 \%$ respectively) were obtained. These acclimated vitroplants presented growth organs whose stem and leaves are well developed (Figure 6) and can be transferred to the field.

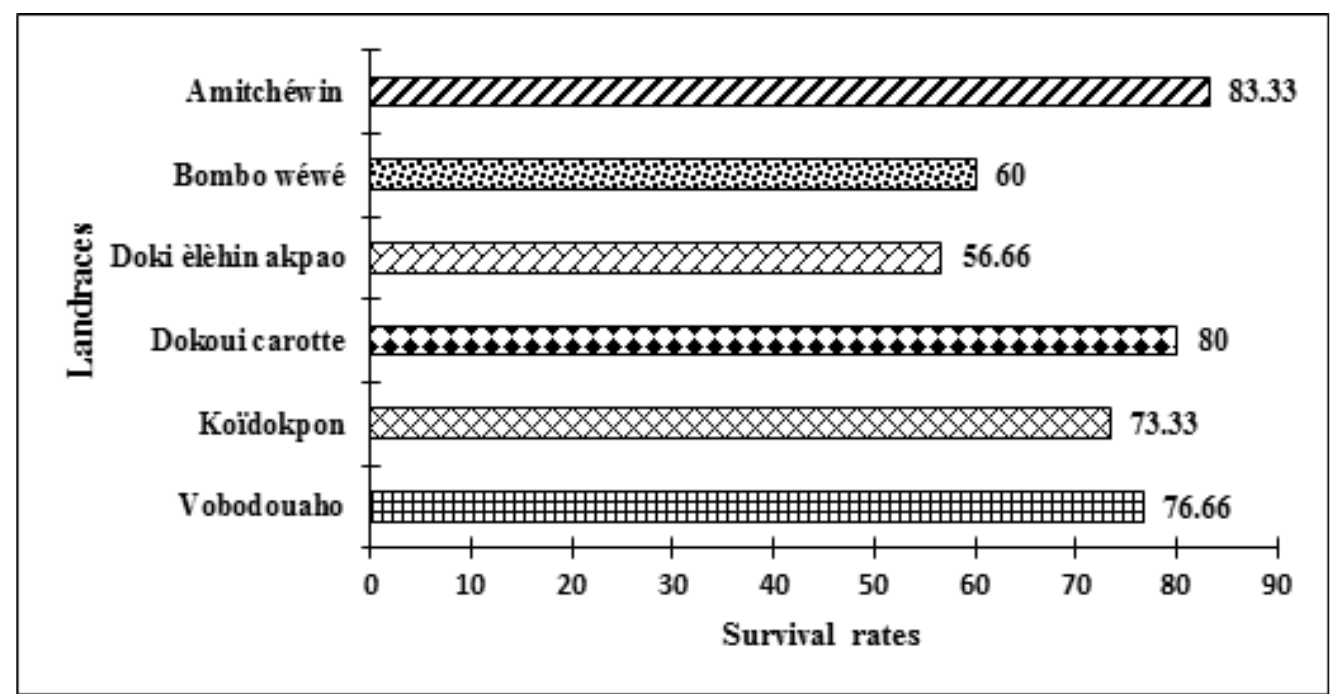

Figure 5 : Averages survival rates of the acclimated vitroplants of sweet potato landraces 


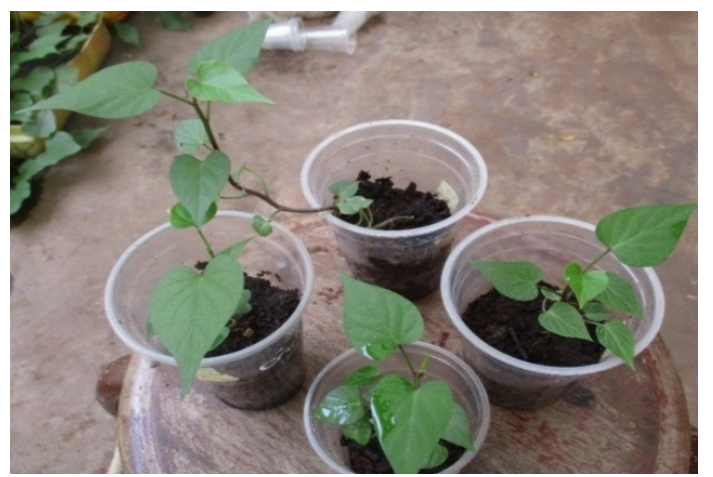

Figure 6 : Vitroplants of the landrace "Amitchéwin" after four weeks.

\section{DISCUSSION}

For bud burst, the response was varied from one landrace to another (12.67 for "Amitchéwin" against 5.67 for "Doki èlèhin akpao"), confirming the analysis of variance which showed a highly significant difference. These results showed that the buds on the same medium would be dependent on the genotype of the different sweet potato landraces. Several works carried out on the sweet potato on the cassava by several authors have shown the influence of genotype on the rate of bud burst on a culture medium (Cacaï et al., 2013; Glato et al., 2014; Kamal et al., 2015). These authors have shown that the MS medium associated with various combinations of growth regulators has an influence on the rate of bud burst, which can reach $100 \%$ in some varieties. An assessment of the rate of bud burst of these landraces in different media with combinations of growth regulators should therefore be considered, especially in landraces with a low bud burst rate on the MS medium without growth regulators. For the effect of Auxin (NAA) and cytokinins (BAP and kinetin) on organogenesis, the analysis of variance of the number of nodes, leaves, roots and shoots height were showed significant differences for the factors varieties, media and their interactions. Only the number of roots formed has not presented significant difference for the "varieties" factor and interaction "varieties *media. This shows the existence of an interaction between growth regulators and genotypes of different landraces. Moreover, the type of cytokinins and its combination or not with the naphthalene acetic acid (NAA) has influenced the formation of nodes, leaves, roots and shoots height. Media containing a combination of BAP and NAA or BAP alone favoured more to the formation of a significant number of nodes and leaves most of the varieties. Thus the MIII medium (MS $+1 \mathrm{mg} . \mathrm{I}^{-}$ ${ }^{1} \mathrm{BAP}+0.1 \mathrm{mg} . \mathrm{l}^{-1} \mathrm{NAA}$ ) allowed to have a maximum number of nodes and leaves in the "Amitchewin", "Bombo wéwé" and "Koïdokpon", as well as the MII medium (MS + 1 mg.l-1 BAP) from "Doki èlèhin akpao". Only "Vobodouaho" landrace has recorded a significant number of nodes and leaves on MV medium containing kinetin and NAA (MS + $\left.1 \mathrm{mg} . \mathrm{l}^{-1} \mathrm{kin}+0.1 \mathrm{mg} . \mathrm{l}^{-1} \mathrm{NAA}\right)$. MVI medium containing a combination of BAP and kinetin (MS $+0.5 \mathrm{mg} . \mathrm{l}^{-1} \mathrm{BAP}+0.5 \mathrm{mg} . \mathrm{l}^{-1} \mathrm{Kin}$ ) has favoured a high number of nodes and leaves in the "Dokoui carotte". These results showed that, on the one hand, the cytokinin-NAA combination was more favourable to the formation of nodes and leaves in most landraces. On the other hand, the BAP has been more effective in the formation of nodes and leaves compared with kinetin for the same concentration. Indeed, even if the media $V$ and $\mathrm{VI}$ (MS + $1 \mathrm{mg} . \mathrm{I}^{-1} \mathrm{Kin}+0.1 \mathrm{mg} . \mathrm{I}^{-1} \mathrm{NAA}$ and MS + $0.5 \mathrm{mg} . \mathrm{I}^{-}$ ${ }^{1} \mathrm{BAP}+0.5 \mathrm{mg} . \mathrm{l}^{-1} \mathrm{Kin}$ ) have produced a significant number of nodes and leaves in "Vobodouaho" and "Dokoui carotte", these media haven't presented significant differences with the MII medium ( MS + $1 \mathrm{mg}$.1 BAP). These results revealed that at equal concentration, BAP is more effective for phyllogenesis compared with kinetin. Onwubiko et al (2015), Sivparsad and Gubba (2012) showed respectively on cassava and sweet potato that a BAP + NAA association with a high BAP /NAA ratio (10/1) is favourable for phyllogenesis and the responses were dependent on the genotypes used. As for the average of the shoots formed, it was found that the medium MIV (MS + 1 mg..$^{-1} \mathrm{Kin}$ ) allowed to have the highest shoot height for "Amitchéwin", "Bombo wéwe" and "Vobodouaho" as well as medium MIII (MS + $1 \mathrm{mg.l}$.1 $^{-1}$ BAP + $0.1 \mathrm{mg} . .^{-1} \mathrm{NAA}$ ) for "Doki èlèhin akpao" and "Koïdokpon". Only "Dokoui carotte" produced tall shoots with MVI medium (MS + 0.5 mg. l-1 $^{-1} \mathrm{BAP}+0.5 \mathrm{mg} . \mathrm{I}^{-1} \mathrm{Kin}$ ). It follows from this result that kinetin alone or in 

vitro of some sweet potato landraces (Ipomoea batatas L.) grown in Benin.

combination with BAP was favourable for growth of the stem. However, the formed leaves are not developed compared to the MIII medium. Dolinski and Oleck on sweet potato and George et al on cassava have shown that a combination of BAP and kinetin was favourable for growth in height of formed shoots (Doliński and Olek, 2013; George et al., 2008). Similarly, a combination of a high concentration of BAP associated with a low NAA concentration is used for better growth of vegetative organs in sweet potato in vitro culture (Wondimu et al., 2012; Yasmin et al., 2011). Thus, the combination BAP/NAA or kinetin/NAA in a ratio greater than one is essential for the production of vitroplants as seed and the establishment of a collection of vitroplants of several sweet potato landraces for purposes preservation. With the roots, analysis of variance (Table 4) showed that only the medium factor was presented a highly significant difference in the number of roots formed. The results obtained (Table 7) showed that most of the media having in addition to cytokinins, the NAA have promoted the formation of the roots, the number of which is high. MV medium (MS + 1 mg. I- $^{-1}$ in + 0.1 mg. I-1 $^{-1} \mathrm{NAA}$ ) improved root formation of the landraces "Bombo wéwé", "Doki

\section{CONCLUSION}

In this study, the effects of different hormonal combinations on the in vitro organogenesis of sweet potato landraces were determined. Of the landraces initiated on the MS medium, four ("Amitchéwin", "Vobodouaho", "Koïdokpon" and "Bombo wéwé") showed high bud burst averages. Organogenesis further revealed that the medium MIII (MS + 1 mg.l-1 BAP + 0.1 mg.l-1 ANA) was more effective for the formation of

\section{ACKNOWLEDGMENTS}

The authors thank Mrs. HOUNGUE Jérôme, ASSOGBA Armel for the corrections brought to the English version of the manuscript and Mrs AISSI Jacques and KOUKE Jaurès, Technicians at the Central Laboratory of Plant

\section{REFERENCES}

Adégbloba YP, 2003. Analyse de la filière patate douce au Bénin. PDRT/MAEP, Rapport final,. 162.

Ahanhanzo C, Agbangla C, Dangou J, Toukourou F, Dansi A, Montcho D, 2008. Influence du chlorure mercurique et de la cytokinine sur la survie et la morphogenèse in vitro d'explants de différents génotypes d'ignames (Dioscorea spp). In Annales des Sciences Agronomiques du Bénin, Vol. 11, 33-47. èlèhin akpao" and "Koïdokpon". Similarly, MIII medium (MS + 1 mg.l-1 BAP + $0.1 \mathrm{mg} . \mathrm{I}^{-1} \mathrm{NAA}$ ) was favourable for the formation of roots for "Vobodouaho". These results indicate that NAA is essential for the formation and elongation of the roots. These results differ from those obtained by Cacai et al (2012) on cassava and which showed that the MS with $0.2 \mathrm{mg} / \mathrm{l} \mathrm{kinetin} \mathrm{was} \mathrm{favourable}$ for root formation. In terms of acclimatization of vitroplants, this study results showed a difference in survival rate of the acclimated vitroplants of each landrace. Outside "Bombo wéwé" and "Doki èlèhin akpao" landraces that gave survival rates of $60 \%$ and $56.66 \%$ respectively, other landraces had a survival rate of over $70 \%$. However, these rates are lower than those obtained by several authors who have worked on sweet potato and have approached 100\% (Demeke et al., 2014; Doliński and Olek, 2013; Glato et al., 2014). This difference observed in the survival rate of vitroplants could be related to the substrate this study used (mixture of compost, sawdust and soil in proportions $2: 1: 1$ ) which is different from that used by these other authors (sterilized compost or soil mixed with sand).

vegetative organs (leaves, nodes and roots) and growth in height of the vitroplants. Finally, the vitroplants produced were successfully acclimatized with survival rates ranging from $56.66 \%$ to $83.33 \%$. This study will contribute for the establishment of in vitro collection of different sweet potato landraces in Benin for their ex situ preservation.

Biotechnology and Plant Breeding of the Faculty of Sciences and Techniques of the Abomey-Calavi University.

Ahanhanzo C, Gandonou C, Agbidinoukoun A, Dansi A, Agbangla C, 2010. Effect of two cytokinins in combination with acetic acid a-naphthalene on yams (Dioscorea spp.) genotypes' response to in vitro morphogenesis. African Journal of Biotechnology 9(51): 8837-8843.

Cacaï G, Ahanhanzo C, Adjanohoun A, Houédjissin S, Azokpota P, Agbangla C, 2013. Hormonal influence on the in vitro bud burst of some 
cassava varieties and accessions from Benin. African Journal of Biotechnology 12(13).

Caca GHT, Ahanhanzo C, Dangou J, Houedjissin S, Agbangla C, 2012. Effets de différentes combinaisons hormonales sur l'organogenèse in vitro de quelques cultivars locaux et variétés améliorées de Manihot esculenta Crantz (manioc-Euphorbiaceae) cultivées au Bénin. International Journal of Biological and Chemical Sciences 6(4): 1593-1607.

Delgado-Paredes G E, Idrogo CR, Chanamé-Céspedes J, Floh El, Handro W, 2016. In vitro direct organogenesis in roots of Ipomoea batatas. Asian Journal of Plant Science and Research 6(3): 17-27.

Demeke Y, Tefera W, Dechassa N, Abebie B, 2014. Effects of plant growth regulators on in vitro cultured nodal explants of cassava (Manihot esculenta Crantz) clones. African Journal of Biotechnology 13(28).

Deng XP, Cheng YJ, Wu XB, Kwak SS, Chen W, Eneji $A E$, 2012. Exogenous hydrogen peroxide positively influences root growth and exogenous hydrogen peroxide positively influences root growth and metabolism in leaves of sweet potato seedlings. Australian Journal of Crop Science 6(11): 1572.

Doliński $R$, Olek A, 2013. Micropropagation of sweet potato (Ipomoea batatas L. Lam) from node explants. Acta Scientiarum Polonorum, Hortorum Cultus 12: 117-127.

Doussoh MA, Dangou-Sossou J, Houédjissin SS, Cacaï GHT, Assogba KA, Ahanhanzo C, 2017. Influence of mercuric chloride on survival and suitability for in vitro regeneration of three sweet potato landraces (Ipomoea batatas L.) produced in Benin. Int. J. Curr. Res. Biosci. Plant Biol. 4(1): 56-64.

Doussoh MA, Dangou J, Houedjissin SS, Assogba KA, Ahanhanzo C, 2016. Analyse des connaissances endogènes et des déterminants de la production de la patate douce [Ipomoea batatas (L.)], une culture à haute valeur socioculturelle et économique au Bénin. International Journal of Biological and Chemical Sciences 10(6): 2596-2616.

Ezeibekwe I, Ezenwaka C, Mbagwu F, Unamba C, 2009. Effects of combination of different levels of Auxin (NAA) and Cytokinin (BAP) on in vitro propagation of Dioscorea rotundata L.(White
Yam). Journal of Molecular Genetics 1(2-4): 1822.

George EF, Hall MA, De Klerk GJ, 2008.Plant tissue culture procedure-background. In Plant propagation by tissue culture, 1-28: Springer.

Glato K, Atsou A, Komi O, Koffi T, Attoh-Mensah M, Djidjolé EK, Dzifa KA, Aziadekey M, Akpavi S, Essozima A, 2014. Régénération In Vitro par organogenèse directe de pousses à partir de boutures de trois cultivars de patate douce (Ipomoea batatas) originaire du Togo. European Scientific Journal, ESJ 10(27).

Glato K, Djidjolé EK, Mensah S, Koffi T, Atsou A, 2013. Comparison of in vitro morphogenetic capacities of different clones of three local cultivars of sweet potato (Ipomoea batatas) from Togo. African Journal of Biotechnology 12(29).

Kamal M, Rahman M, Haque M, 2015. Effect of Growth Regulator on Regeneration of Sweet Potato (Ipomoea Batatas L.). Journal of Environmental Science and Natural Resources 6(2): 197-200.

Murashige T, Skoog F, 1962. A revised medium for rapid growth and bio assays with tobacco tissue cultures. Physiologia plantarum 15(3): 473-497.

Ndagijimana V, Kahia J, Asiimwe T, Sallah PY, Waweru B, Mushimiyimana I, Ndirigwe J, Sindi K, Shumbusha D, Njenga $P, 2014$. In vitro effects of gibberellic acid and sucrose concentration on micropropagation of two elite sweet potato cultivars in Rwanda.

Onwubiko N, Ihezie $\mathrm{Cl}$, Mozie $\mathrm{M}, 2015$. In vitro regeneration of sweet potato (Ipomea batatas (L.) Lam.) from node explants. Amer. J. Experimental Agriculture 8(2): 87-92.

Paraïso A, Olodo PG, Tokoudagba SF, Yegbemey RN, Sanni A, Gutmetzoe M, 2013. Sweet Potato (Ipomoea Batatas L.) Production Determinants in North-East Benin: The Commune of Gogounou as a Case in Point. International Journal of Science and Advanced Technology 3(1): 14-20.

Sanoussi A, Dansi A, Ahissou H, Adebowale A, Sanni L, Orobiyi A, Dansi M, Azokpota P, Sanni A, 2016. Possibilities of sweet potato [Ipomoea batatas (L.) Lam] value chain upgrading as revealed by physico-chemical composition of ten elites landraces of Benin. African Journal of Biotechnology 15(13): 481-489.

Sanoussi A, Dansi A, Bokossa-yaou I, Dansi M, Egounlety M, 2013. Formulation and biochemical characterization of sweet potato 
(Ipomoea batatas) based infant flours fortified with soybeanand sorghum flours. Int. J. Curr. Microbiol. App. Sci 2(7): 22-34.

Saucedo-Ruiz M, Delgado-Sánchez $P$, GuzmanMaldonado S, Villordo-Pineda E, AcostaGallegos J, Mora-Aviles M, 2006. Organogenic Plant Regeneration System for the Common Bean (Phaseolus vulgaris L). Annual ReportBean Improvement Cooperative 49: 121.

Sivparsad B, Gubba A, 2012. Development of an efficient plant regeneration protocol for sweet potato
(Ipomoea batatas L.) cV. Blesbok. African Journal of Biotechnology 11(84): 14982-14987.

Wondimu T, Feyissa T, Bedadav G, 2012. Meristem culture of selected sweet potato (Ipomoea batatas L. Lam.) cultivars to produce virus-free planting material. The Journal of Horticultural Science and Biotechnology 87(3): 255-260.

Yasmin A, Jalbani A, Raza S, 2011. Effect of growth regulators on meristem tip culture of local potato cvs. Desiree and Patrones. Pakistan Journal of Agriculture, Agricultural Engineering, and Veterinary Science 27(2): 143-149. 